\title{
Analysis of Meat Consumption Pattern in Ogbomoso North Local Government Area, Oyo State, Nigeria
}

\section{${ }^{* 1}$ AROWOLO, OV; ${ }^{2}$ OLADEJO, JA; ${ }^{1}$ OGUNTOYE TO; ${ }^{1}$ KABIR GB; ${ }^{1}$ SALAKO, BA}

\author{
${ }^{*}$ Department of Forest Economics and Extension, Forestry Research Institute of Nigeria, Jericho Hill, Ibadan, Nigeria \\ ${ }^{2}$ Department of Agricultural Economics, Ladoke Akintola University of Technology, Ogbomoso Oyo State, Nigeria \\ *Corresponding Author Email: atolanilayinka@ gmail.com, Tel: +2347038216249
}

\begin{abstract}
The increasing awareness of the benefits of more nutritious, healthier and safer food products by consumers plays a vital role in the recent changes experienced in the food production chain, and meat products are no exception to this. The study investigated consumption pattern of meat in Ogbomoso North Local Government Area, Oyo State, Nigeria. Primary data for the study were obtained from 120 respondents with the use of structured questionnaire analysed using descriptive statistics and inferential statistics. According to the study, chicken, turkey and beef with percentage frequencies $96.7 \%, 81.7 \%$ and $76.8 \%$ respectively were the most consumed meat types, while quail, rabbit and guinea fowl with percentage frequencies $6.7 \%, 7.5 \%$ and $12.5 \%$ respectively were the least consumed meat types. Also, income of the respondent with $\mathrm{t}$-value 41.08 and a positively signed coefficient at $1 \%$ level of significance was found to have a direct effect on the monthly expenditure on preferred meat type. The study recommend there should be awareness on the nutritional benefits of consuming meats of low saturated fats and calorie contents such as rabbit, quail and guinea fowl and also to teach them how to raise these animals domestically.
\end{abstract}

\section{DOI: https://dx.doi.org/10.4314/jasem.v25i4.10}

Copyright: Copyright $(92021$ Arowolo et al. This is an open access article distributed under the Creative Commons Attribution License (CCL), which permits unrestricted use, distribution, and reproduction in any medium, provided the original work is properly cited.

Dates: Received: 14 February 2021; Revised: 26 March 2021; Accepted: 12 April 2021

Keywords: Meat, Consumption, Nutritional, expenditure, preferences, Oyo state.

Consumers in any production system play a vital role around which the whole system revolves and meat products are no exception to this. With the rising income levels of the consumers and their changing tastes and preferences, the demand for meat is undergoing a change both in quantitative and qualitative terms. Two types of differentiated meat products that have gained popularity are grass-fed meats and locally produced meats. Part of the motivation behind increased grass-fed meat purchases is the nutritional aspect, as grass-fed meats have been found to be leaner (lower in saturated fats and calorie content) than conventional meats and higher in Omega-3 fatty acids (Clancy, 2006). Meat consumption will, in line with the economic development and the growing world population, grow worldwide. The increase is highest in poultry consumption, lower in pork and beef. Overall, the demand for grain and other traditional food will decrease in favor of animal foods (DBV 2012). Meat is the most valuable livestock product and for many people, it serves as their first choice source of animal protein (Tsegay, 2012). Meat is any flesh of animal that is used for food; it is nutritious and highly attractive in appearance (Akinwumi, et al., 2011). It is a nutritious food containing quantities of essential amino acids in forms of protein. It contains B group vitamins (especially niacin and riboflavin), iron, phosphorus, ash and calcium (Obi 2000). There are different kinds of meat depending on the source from which they are obtained, for example, mutton from sheep, chevon from goat, beef from cattle, pork from pig and chicken from birds (Soniran and Okubanjo, 2002). Preferential consumption exists in spite of the importance of meat as a source of protein with high biological value, household demand for meat products such as beef, mutton, pork, chevon, chicken, quail meat, rabbit meat and guinea fowl meat are faced with problems, earlier reports classified factors that affect the consumption of meat as economic, social and cultural. Ojewola and Onwuka, (2001) specifically highlighted religion, age, sex, individual variation and income as major factors affecting meat consumption in Nigeria. The demand for meat in domestic market is rising at the rate of $2.8 \%$ for beef, $2.9 \%$ for mutton, and $6.10 \%$ for poultry, consumption of meat is increasing due to population growth, human need for protein and calcium and improving consumption patterns (Sindh Board of Investment, 2013), consumers are beginning to realize that certain common and readily available meat types are not as healthy as some uncommon ones. However, 
consumers do not seem to be ready to compromise the sensory features of their food products for potential benefits to their health (Ares, et al., 2010; Tuorila and Cardelo, 2002; Verbeke, 2006). An important percentage of consumers prefer to diminish their intake of certain products or even avoid them rather than consume a supposedly healthy and tasteless version (Guerrero, et al., 2011). The nutritional awareness of meat, the perceived unhealthiness, concerns about additives or the perceived fat content cannot be under estimated (Verbeke \& Viaene 2000; Lea \& Worsley 2001). The aspect of healthy meat consumption plays an important role especially red meat which is associated with a higher risk of health complaints like coronary heart disease, diabetes, cancer (Chao et al. 2005; Tavani et al. 2000). However, several studies have been carried out on analysis of meat consumption. (Alimi 2013), Akinsula, et al., (2019) factors influencing meat consumption and Analysis of household demand for meat ( Adetunji and Rauf, 2012). This study therefore seeks to investigate consumption pattern of meat and to determine the factors influencing respondents' monthly expenditure on meat in the study area with a view to creating more awareness on domestication and consumption of meats types that are low in saturated fats and calorie contents but high in fatty acids and other essential nutrients.

\section{MATERIALS AND METHODS}

Study Area: The study was conducted in Ogbomosho North Local Government Area of Oyo State, Nigeria. ogbomoso is a city in Oyo state, south western Nigeria, founded in the mid- $17^{\text {th }}$ century. It is located within the tropical region with distinctive wet (April-October) and dry (November-December) seasons. Average temperature in the region is $31{ }^{\circ} \mathrm{C}$ while total annual rainfall is about $1800 \mathrm{~mm}$. The temperature is persistently high with an annual range of about $5^{\circ} \mathrm{C}$. ogbomoso is a pre-colonial urban center and the second largest city, both in terms of population and spatial extent in Oyo state, Nigeria. The population was approximately 645,000 in 2006 census (Ogunbode and Fabiyi, 2019). Ogbomoso North is the largest local government in the city, being the city's major economic nerve. It is an area of mixed culture with an appreciable standard of living and the most populous local government in the city as at the 2006 census. The majority of the people are members of the Yoruba ethnic group and Yam, cassava, maize, and tobacco are some of the notable agricultural products of the region.

Method of data Collection and Analysis: Primary data for the study was collected through structured questionnaire, which was used to elicit information from the respondents on their meat consumption pattern and share of expenditure on meat types. Multistage sampling technique was used to select a sample size of 120 respondents. In the first stage, six wards out of the ten wards in the LGA were randomly selected. In the second stage, twenty households were systematically selected from each of the six wards. In the last stage, the household head in each of the selected households was interviewed. This makes a total of one hundred and twenty (120) respondents. The data collected on the field were subjected to both descriptive statistics (such as means, frequency and Percentage) and inferential statistics (such as OLS regression analysis). Ordinary least square (OLS) is more commonly named linear regression (simple or multiple depending on the number of explanatory variables).In the case of a model with $\mathrm{p}$ explanatory variables, the OLS regression model writes:

$$
Y=\beta_{0}+\Sigma_{j=1 . . p} \beta_{j} X_{j}+\varepsilon
$$

where $\mathrm{Y}$ is the dependent variable, $\beta_{0}$, is the intercept of the model, $\mathrm{X}_{\mathrm{j}}$ corresponds to the $\mathrm{j}^{\text {th }}$ explanatory variable of the model ( $j=1$ to $p$ ), and $\varepsilon$ is the random error with expectation 0 and variance $\sigma^{2}$.In the case where there are $n$ observations, the estimation of the predicted value of the dependent variable $\mathrm{Y}$ for the $i^{\text {th }}$ observation is given by:

$$
y_{i}=\beta_{0}+\Sigma_{j=1 . . p} \beta_{j} X_{i j}
$$

For this study, it was used to test for the level of relationship or significance between the monthly expenditure on meat (dependent variables) and socio economic characteristics of respondents (independent variables). Therefore;

$\mathrm{Y}=$ monthly expenditure on meat in naira (dependent variable); While X1 =Age (Years); X2 = Level of education (Years), X3 $=$ Marital status (married $=1$, otherwise $=0$ ); X4 = Household size (Actual); X5 = Monthly income ( X6 = Sex (male $=1$, otherwise $=0) ; \mathrm{X} 7=$ Tribe $($ Yoruba $=1$, Otherwise $=0$ )

\section{RESULTS AND DISCUSSION}

Socio-economic Characteristics of the Respondents: From the table below, a high percentage (49\%) of the respondents were under 30 years of age, $30 \%$ falls within the age range 31 and 40 years, $17 \%$ fall within ages 41-50 and 3.3\% falls within ages 51-60. The mean age is 33 years which implies that majority of the respondents are still within the economically productive age. This validates the discovery of Akinsulu et al., (2019), who reported a mean age of 48.36 years implying that respondents in Ijebu-ode were also economically active youths. Also, $55 \%$ of 
the respondents were traders while the remaining $45 \%$ spread across the other occupations, so it is safe to say that the inhabitants of Ogbomoso north local government area of Oyo state are primarily traders.

Table 1: Socio- economic characteristic of the respondents

\begin{tabular}{|c|c|c|}
\hline Variable & Frequency & Percentage \\
\hline \multicolumn{3}{|l|}{$\mathrm{AGE}$} \\
\hline$\leq 30$ & 59 & 49.2 \\
\hline $31-40$ & 36 & 30.0 \\
\hline $41-50$ & 21 & 17.5 \\
\hline 51 and above & 4 & 3.3 \\
\hline Total & 120 & 100 \\
\hline \multicolumn{3}{|l|}{ GENDER } \\
\hline Male & 67 & 55.8 \\
\hline Female & 53 & 44.2 \\
\hline Total & 120 & 100 \\
\hline \multicolumn{3}{|l|}{ Tribe } \\
\hline Yoruba & 101 & 84.2 \\
\hline Hausa & 10 & 8.3 \\
\hline Igbo & 9 & 7.5 \\
\hline Total & 120 & 100 \\
\hline \multicolumn{3}{|l|}{ Religion } \\
\hline Islam & 33 & 27.5 \\
\hline Christianity & 86 & 71.7 \\
\hline Traditional & 1 & 0.8 \\
\hline Total & 120 & 100 \\
\hline \multicolumn{3}{|l|}{ Marital status } \\
\hline Single & 58 & 48.3 \\
\hline Married & 61 & 50.8 \\
\hline Widowed & 1 & 0.8 \\
\hline Total & 120 & 100 \\
\hline \multicolumn{3}{|l|}{ Educational Lerel } \\
\hline Non formal education & 1 & 0.83 \\
\hline Primary & 21 & 17.50 \\
\hline Secondary & 43 & 35.83 \\
\hline Tertiary & 55 & 45.83 \\
\hline Total & 120 & 100 \\
\hline \multicolumn{3}{|l|}{ Primary occupation } \\
\hline Trader & 66 & 55.00 \\
\hline Farmer & 13 & 10.83 \\
\hline Cilvil servant & 14 & 11.67 \\
\hline Artisans & 27 & 22.50 \\
\hline Total & 120 & 100 \\
\hline \multicolumn{3}{|l|}{ Household Size } \\
\hline$\leq 3$ & 74 & 61.67 \\
\hline 4 and above & 46 & 38.33 \\
\hline Total & 120 & 100 \\
\hline \multicolumn{3}{|l|}{ Monthly income(*) } \\
\hline$<15000^{\circ}$ & 82 & 69.33 \\
\hline $15000-20000$ & 33 & 27.50 \\
\hline Above 20000 & 5 & 4.17 \\
\hline Total & 120 & 100 \\
\hline
\end{tabular}

Source: Field Survey, 2018

Furthermore, $55.8 \%$ of the respondents are males while $44.2 \%$ are females' and $71.7 \%$ are Christians, $27.5 \%$ are Muslims and $0.8 \%$ are traditional worshippers. Likewise, $45.8 \%$ are educated up to the tertiary level, while $35.8 \%$ and $17.5 \%$ are educated up to the secondary and primary level respective and only $1 \%$ of the respondents has no formal education. This is an indication of high level of formal education in the study area which may increase the consumer's awareness on the nutritive value of meat in human diet as concluded by Akinsulu et al., (2019).In addition to the above, $61 \%$ of the respondents were married, with $62 \%$ having a household size between 1 - 3members and with about $68 \%$ earn less than $\$ 15,000$ per month.
Availability of meat types in the study area: Table 2 shows that Turkey, Chicken, Chevon and Beef with percentage frequencies $97.5 \%, 94.2 \%, 83.3 \%$ and $82.5 \%$ respectively are the most available meat types in the study area while Pig, Quail, Rabbit and Guinea fowl meat with percentage frequencies $4.2 \%, 4.2 \%$, $8.3 \%$ and $12.5 \%$ respectively are the least available meat types in the study area. This agrees with the discovery of Akinsula et al., (2019) who reported meats from cattle (beef) as the most preferred meat type due to its availability.

Table 2: Availability of Meat Types in the Respondents Area

\begin{tabular}{lll}
\hline Meat type & Frequency & Percentage \\
\hline Turkey & 117 & 97.50 \\
Chicken & 113 & 94.20 \\
Chevon & 100 & 83.30 \\
Beef & 99 & 82.50 \\
Mutton & 29 & 24.20 \\
Guinea fowl & 15 & 12.50 \\
Rabbit meat & 10 & 8.30 \\
Quail & 5 & 4.20 \\
Pig & 5 & 4.20 \\
\hline \multicolumn{2}{c}{ Source: } & Field Survey, 2018
\end{tabular}

Table 3: Meat Consumption Pattern of Respondents in the Study

\begin{tabular}{|c|c|c|}
\hline \multicolumn{3}{|c|}{ Area } \\
\hline VARIABLE & Frequency & Percentage \\
\hline \multicolumn{3}{|l|}{ Turkey } \\
\hline Do not consume & 22 & 18.3 \\
\hline Consume & 98 & 81.7 \\
\hline Total & 120 & 100 \\
\hline \multicolumn{3}{|l|}{ Chicken } \\
\hline Do not consume & 4 & 3.3 \\
\hline Consume & 116 & 96.7 \\
\hline Total & 120 & 100 \\
\hline \multicolumn{3}{|l|}{ Beef } \\
\hline Do not consume & 28 & 23.3 \\
\hline Consume & 92 & 76.8 \\
\hline Total & 120 & 100 \\
\hline \multicolumn{3}{|l|}{ Chevon } \\
\hline Do not consume & 68 & 56.7 \\
\hline Consume & 52 & 43.3 \\
\hline Total & 120 & 100 \\
\hline \multicolumn{3}{|l|}{ Quiinea fowl } \\
\hline Do not consume & 105 & 87.5 \\
\hline Consume & 15 & 12.5 \\
\hline Total & 120 & 100 \\
\hline \multicolumn{3}{|l|}{ Rabbit } \\
\hline Do not consume & 111 & 92.5 \\
\hline Consume & 9 & 7.5 \\
\hline Total & 120 & 100 \\
\hline \multicolumn{3}{|l|}{ Quail } \\
\hline Do not consume & 112 & 93.3 \\
\hline Consume & 8 & 6.7 \\
\hline Total & 120 & 100 \\
\hline \multicolumn{3}{|l|}{ Pork } \\
\hline Do not consume & 91 & 75.8 \\
\hline Consume & 28 & 24.2 \\
\hline Total & 120 & 100 \\
\hline
\end{tabular}

Meat Consumption Pattern of Respondents in the Study Area: Table 3 presents meat consumption pattern by the respondents in the study area. Majority (97\%) of the respondents consumed chicken in the 
study area. This is directly followed by Turkey which was consumed by $(82 \%)$ of the respondents and then Beef by $77 \%$. This upholds the conclusions of Alimi (2013) who report beef, chicken and turkey as the most preferred in the study area. The least consumed meat types include Quail, Rabbit and Guinea Fowl with percentages of consumption $6.7 \%, 7.5 \%$ and $12.5 \%$ respectively.

Table 4: Average monthly expenditure on meat by respondents

\begin{tabular}{ll}
\hline Type of meat & Mean Monthly Expenditure $(\mathrm{N})$ \\
\hline Chicken & 1182.50 \\
Quail & 54.17 \\
Guinea Foul & 170.00 \\
Turkey & 764.17 \\
Beef & 728.75 \\
Rabbit & 100.00 \\
Chevon & 403.89 \\
Mutton & 249.58 \\
Pork & 161.67 \\
\hline \multicolumn{2}{r}{ Source Field Survey, 2018 }
\end{tabular}

Monthly expenditure on different types of meat by respondents in the area: The results on table 4 revealed the average monthly expenditure on different meat types by the respondents. The meat types upon which the respondents spend more, averagely include; Chicken (N1182.50), Turkey (N764.17) and Beef (N728.75), while the meat types upon which the respondents spend less, averagely include; Quail (N54.17), Rabbit (N100.00) and Guinea fowl (N170.00). This implies that the respondents' highest monthly expenditure was chicken, that is, they consume more of chicken than any other meat types. This was followed by turkey and beef respectively.

Result of Regression Analysis: Regression analysis was carried out to establish the relationship between socioeconomic characteristics of respondents and monthly expenditure on meat. The regression result according to table 5 shows that the explanatory variables explained $94.93 \%$ of the variations in the dependent variable, while the remaining $5.07 \%$ was due to error which were not included in the variables. The F-value was 279.74 and significant at $1 \%$, showing the goodness of fit of the regression model. From the result, the respondents' income has a t-value 41.08 and a positively signed coefficient at $1 \%$ level of significance. This implies that the respondents' income has a direct effect on the monthly expenditure on preferred meat type. The religion has $\mathrm{t}-$ value of 1.63 and a positively signed coefficient at $10 \%$ level of significance. This implies direct effect. This is probably because some religion considers eating particular type of meat as taboo.

Therefore, the model now becomes;

$$
\begin{aligned}
& \mathrm{Y}=11454.41-18.13 \mathrm{X}_{1}+7.36 \mathrm{X}_{2}+23.32 \mathrm{X}_{3}+ \\
& 137.85 \mathrm{X}_{4}-126.54 \mathrm{X}_{5}+5.85 \mathrm{X}_{6}+43.26 \mathrm{X}_{4}+ \\
& 3001.261 \mathrm{X}_{8} \\
& \mathrm{R}^{2}=94.93 \% \text { i.e } 0.9493, \mathrm{~F}-\text { value }=279.74
\end{aligned}
$$

\begin{tabular}{lcccc}
\multicolumn{5}{c}{ Table 5: Result of regression analysis } \\
\hline Coefficient & Std. Err. & \multicolumn{1}{c}{$\mathrm{t}$} & $\mathrm{P}>|\mathrm{t}|$ \\
\hline Sex & 7.361597 & 6.064646 & 1.21 & 0.227 \\
Tribe & -18.13338 & 77.39324 & -0.23 & 0.815 \\
Marital status & 5.846642 & 48.17513 & 0.12 & 0.904 \\
Religion & -126.5433 & 107.1345 & -1.18 & 0.240 \\
Educational level & 137.8508 & $84.68091^{*}$ & 1.63 & 0.106 \\
Household size & 23.32105 & 35.14213 & 0.66 & 0.508 \\
Income & 43.26748 & 35.33788 & 1.22 & 0.223 \\
Constant & 3001.261 & $73.06351^{* * *} *$ & 41.08 & 0.000 \\
\hline \multicolumn{5}{c}{ Source: Field Survey, 2018 } \\
\end{tabular}

Conclusion: Chicken is the most consumed meat type by the respondents. This is followed by turkey and beef. The least consumed meat types in the study area include quail, rabbit, guinea fowl and pork. From the result of the multiple regressions it can also be concluded that respondent's income and religion are the major factors influencing respondents' monthly expenditure on meat in the study area.

There should be awareness creation on the benefits of consuming other meats (e.g rabbit, quail and guinea fowl) that are low in saturated fats and calorie contents but high in fatty acids and other essential nutrients.

\section{REFERENCE}

Adetunji, MO; Rauf, MO (2012). Analysis of Household Demand for Meat, in Southwest, Nigeria. Global J Sci. Front. Res. Agric. Bio. 12 (1) Online ISSN: 2249-4626

Akinsulu, AA; Ajibola S., Odetola, SK; Awoyemi, DO (2019). Factors Influencing Meat Consumption in Ijebu-North Local Government Area of Ogun State Nigeria. J. Market. Consumer Res. 52: 10-16

Akinwumi, AO; Odunsi, AA; Omojola, AB; Aworemi, JR; Aderinola, OA. (2011). Consumer 
Perception and Preference for Meat Types in Ogbomoso Area of Oyo State, Nigeria. Inter. J Appl. Agric. Apicultural Res. 7(1-2): 96-106.

Alimi, RS (2013). An Analysis of Meat demand in Akungba-Akoko, Nigeria. Nig. J. Appl. Behavioral Sci. 1:96-104

Ares, G; Barreiro, C; Deliza, R; Giménez, A; Gámbaro, A (2010). Consumer Expectations and Perception of Chocolate Milk Desserts Enriched with Antioxidants. J. Sensory Stud. 25: 243-250.

Chao, A; Thun, M.J; . Connell, CJ; McCullough, M.L; Jacobs, EJ; Flanders, WD; Rodriguez, C; Sinha, R; Calle, EE (2005). Meat consumption and risk for colorectal cancer. Am. J. Am. Med. Assoc. 293 (2): 172-182.

Clancy, K (2006). "Greener Pastures: How Grass-Fed Beef and Milk Contribute to Healthy Eating." Publication of the Union of Concerned Scientists. Online. Available at www. ucsusa.org/assets/ documents/food_and_environment/greenerpastures.pdf.

DBV (Deutscher Bauernverband). (2012). Situations bericht 2013 - Trends und Fakten zur Land wirtschaft. Berlin.

Guerrero, L; Claret, A; Bernardo, J; Mauri, M; Comaposada, J; Arnau, J (2011). Consumers' Acceptability and Expectations towards Meat Products Without added Sodium Chloride.9th Pangborn Sensory Science Symposium.4-8 September, Toronto, Canada.

Lea, E; Worsley, A (2001). Influences on meat consumption in Australia. Appetite 36 (2): 127 136.
Obi, CI (2000).Game Production an Accumulative to Beef Game Production. An Alternative to Beef Cattle Production in Southern Nigeria Forum, 4: 36-40.

Ogunbode, T; Fabiyi, I (2019). Rainfall Trends and its Implications on Water Resources Management: A Case Study of Ogbomoso City in Nigeria. International Journal of Hydrology. 3(3): 210215

Ojewola, GS; Onwuka, GI (2001). Evaluation of the Organoleptic Properties of "Suya" Produced from Various Sources of Meat. Nigerian Journal of Animal Production 28 (2): 199- 201.

Soniran, OG; Okubanjo, AO (2002).PhysicoChemical and Sensory Characteristics of Pork Loin Roast Cooked to Three Internal Temperatures. Nig. J. Animal Production, 29(1): 138- 141

Tavani, A; Veccina, CL; Gallus, S; Lagiou, P; Trichopoulus, D; Levi, F; Negri, E (2000). Red meat intake and cancer risk: A study in Italy. Inter. J. Cancer 86: 425-428.

Tsegay, H (2012). Consumer Perception and Preferences of Meat Types in Harare and Haramaya Province, Ethiopia. J. Microbiol. Biotechnol. Food Sci. 2(3): 959.

Verbeke, W; Pérez-Cueto, JA; Barcellos, MD; Krystallis, A (2010). European citizen and consumer attitudes and preferences regarding beef and pork. Meat Sci. 84 (2): 284-292. 